of peat-vermiculite or calcined clay when soil temperatures exceeded 30C. Additional cultural and economic evaluations are needed to assess the feasibility of using transplants as an alternative production method. Based on the available marketing, production, and economic information, fall broccoli has potential as a new enterprise for Virginia, provided the average yield exceeds 160 cartons/ha and the harvest season ends before the first week in December (week 48).

\section{Literature Cited}

Bauer, L. L., R. Caines, P.J. Rothwell, and G.J. Wells. 1987. Using the market window techniques to assess market potential for vegetables. Acts Hort. 203:197-203.

Chung, B. 1985. The effects of sowing time and plant density on the once-over harvest yields of broccoli. J. Hort. Sci. 60:57-64.

Council for Agricultural Science and Technology. 1984. Development of new crops: Needs, procedures, strategies, and options. CAST Rpt. 102.

Cutcliffe, J.A. 1975. Effect of plant spacing on single-harvest yields of several broccoli cultivars. HortScience 10:417-419.

Dufault, R.J. and L. Waters, Jr. 1985. Interaction of nitrogen fertility and plant populations on transplanted broccoli and cauliflower yields. HortScience 20:127-128.

Elson, M.K. and R. Morse. 1989. Influence of soil moisture and planting depth on emergence of broccoli seedlings. ASHS 1989 Annu. Mtg., Tulsa, Okla., Prog. \& Abstr. p. 126.

Federal-State Market News Service. 1987. Fresh fruit and vegetables wholesale market prices (by terminal market). USDA, Agr. Mkt. Serv., Fruit and Veg. Div., Market News Branch.

Green, J. and N.G. Schuck. 1988. Do your own market research, p. 80-85. In: D.T. Smith (cd.). Marketing U.S. agriculture. 1988 Yrbk. of Agr., U.S. Govt. Printing Office, Washington, D.C.

Harem, S.R. 1988. Vegetables and specialties situation and outlook report. USDA, Econ. Res. Serv. TVS-245 (Sept. 1988).

Kline, R. A., P. Minotti, D. Wolfe, P. Stevens, D. Bell, C. Tenbrock, J. Port, L. Ward,, and B. Henehan. 1986.1985 Specialty crops in trial. Cornell Univ. Veg. Crops Rpt. 334.

National Oceanic and Atmospheric Administration. 1987. Virginia. Clim. Data Annu. Summary. 97(13):8.

O'Dell, C. R., R. Morse, P. Ramsey, and A. Borowski. 1989. Fall broccoli production-A guide for southside Virginia farmers. Virginia Coop. Ext. Serv. Publ. 438-011.

Perkins-Veazie, P.M. and D.J. Cantliffe. 1989 Improved stand establishment of direct-seeded cabbage with seed covers. J. Amer. Soc. Hort. Sci. 114:36-39.

Runyan, J. L., J.P. Anthony, Jr., K.M. Kesecker, H.S. Ricker, C.W. Coale, Jr., and C.R. O'Dell. 1986. Determining commercial marketing and production opportunities for small farm vegetable growers. USDA Agr. Mktg. Serv., Mktg. \& Res. Rpt. 1146.

SAS Institute; Inc. 1985. SAS user's guide: Statistics. SAS Inst., Inc., Cary, N.C.

Sterrett, S. B.; C.W. Coale, Jr., T.A. Fretz, and C.R. O'Dell. 1989. Vegetable crop diversification-A systems approach. HortScience 24:539-540.

Tinga, J.H. and M.H. Bailey. 1967. Freeze probabilities in Virginia and protection practices. VPI Res. Div. Res. Rpt. 119.

U.S. Department of Agriculture. 1943. United States standards for broccoli. Agr. Mkt. Serv.

HorTSCIENCE 25(6):641-644. 1990.

\title{
Scheduling Irrigations for Carrots
}

\author{
E. Gordon Kruse ${ }^{1}$, James E. Ells ${ }^{2}$, and Ann E. McSay \\ Colorado State University, Fort Collins, CO 80523
}

Additional index words. Daucus carota, water use efficiency, crop coefficients

Abrastract. A 3-year irrigation scheduling study on carrots (Daucus carota L.) was conducted at the Colorado State Univ. Horticulture Research Center near Fort Collins to determine the irrigation schedule that produced the best combination of high water use efficiency and marketable yields with the least amount of water and fewest irrigations. This study used an irrigation scheduling program developed by the U.S. Department of Agriculture/Agricultural Research Service with crop coefficients calculated for carrots. Maximum carrot production and water use efficiency were obtained when the scheduling program simulated a $30-\mathrm{cm}$ rooting depth at planting, increasing linearly to $60 \mathrm{~cm}$ in 75 days. Best yields and water use efficiency were attained by irrigating whenever $40 \%$ of the available water in the root zone had been depleted. The computer program for irrigation scheduling is available on diskette from the authors.

In arid land, the amount and timing of irrigation for many crops is still largely left to the judgment of the irrigator. Since water represents an essential and often costly input for carrot production, the purpose of this study was to develop an irrigation scheduling program for carrots that would aid irrigators in deciding when and how much water to apply.

by the moisture level of the soil or plant. Soil moisture may be determined by feel, gravimetric sampling, gypsum blocks, tensiometers, or neutron probes (Donahue et al., 1977). Water stress level in the plant may be determined by infrared thermometers (Jackson, 1982), pressure bombs (Tyree and Hammel, 1972), or ultra-microphones that sense breaking capillaries (Hanan, 1987). The problem with all of these methods is that they require visits to each field, and, when many fields and crops are involved, this can be time-consuming and costly.

The desired irrigation schedule should produce high carrot yields and high water use efficiencies (WUE) while minimizing the number of irrigations and total depth of water applied. Water use efficiency is defined as the yield of carrots (in kilograms per hectare) produced for each millimeter of water applied, including rain. Irrigation scheduling variations were evaluated on replicated small plots. The scheduling treatments were modified each year, based on the previous year's results.

Our irrigation scheduling approach was to

Received for publication 19 Apr. 1989. Contribution from USDA/ARS and Dept. of Horticulture, Colorado State Univ. Funding provided by Colorado Agricultural Experiment Station (Project 156), Colorado State Univ. Development Fund (Project 5195), and Colorado State Univ. Contracts and Grants (Project 1010). The cost of publishing this paper was defrayed in part by the payment of page charges. Under postal regulations, this paper therefore must be hereby marked advertisement solely to indicate this fact.

'Agricultural Engineer, USDA-ARS Irrigation and Drainage Research Unit.

${ }^{2}$ Associate Professor, Dept. of Horticulture.

${ }^{3}$ Researcher I, Dept. of Horticulture. maintain a daily soil water budget using the Penman equation as modified by Jensen (1969). Daily crop water use or evapotranspiration $\left(\mathrm{E}_{\mathrm{t}}\right)$ was calculated by multiplying the reference $\mathrm{E}_{\mathrm{t}}$ by crop coefficients based on crop and stage of growth (Kincaid and Heermann, 1974). The equation used was: $E_{t}=K_{c} E_{t p}+K_{r}\left(0.9-K_{c}\right) E_{t p}$, where: $\mathrm{E}_{\mathrm{t}}=$ daily evapotranspiration; $\mathrm{E}_{\mathrm{tp}}=$ potential evapotranspiration for reference crop (alfalfa); $\mathrm{K}_{\mathrm{c}}=$ crop coefficient determined by the stage of growth and soil water depletion $\left(\mathrm{K}_{\mathrm{c}}=\mathrm{K}_{\mathrm{co}} \mathrm{K}_{\mathrm{s}}\right)$; $\mathrm{K}_{\mathrm{co}}=$ ratio of $\mathrm{E}_{\mathrm{t}}$ for crop in question, when soil water is not limiting and soil surface evaporation is negligible, to the reference crop $\mathrm{E}_{\mathrm{t}} ; \mathrm{K}_{\mathrm{s}}=$ stress factor that drops below 1.0 as soil water is depleted; $\mathrm{K}$ $=$ coefficient taking on the values of 0.8 for the first day, 0.5 for the 2 nd day, 0.3 for the 3 rd day, and 0.0 for subsequent days, following rainfall or irrigation.

This model calculates daily water deficit using 1) water-holding capacity of the soil, 2) current assumed rooting depth, 3) amount of effective rain, and 4) the calculated $E_{r}$.

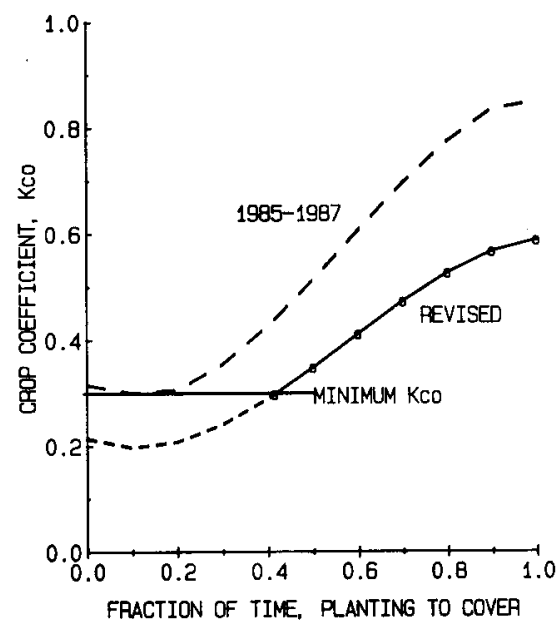

Fig. 1. Crop coefficient curves for irrigation scheduling of carrots before effective cover. The dashed line (1985-1987) represents the coefficients assumed for the 3-year field study. The revised curve (solid line) duplicates the irrigation treatment that gave highest yield and best water use efficiency in each of the three years. 
Table 1. Carrot irrigation treatments, 1985-1987.

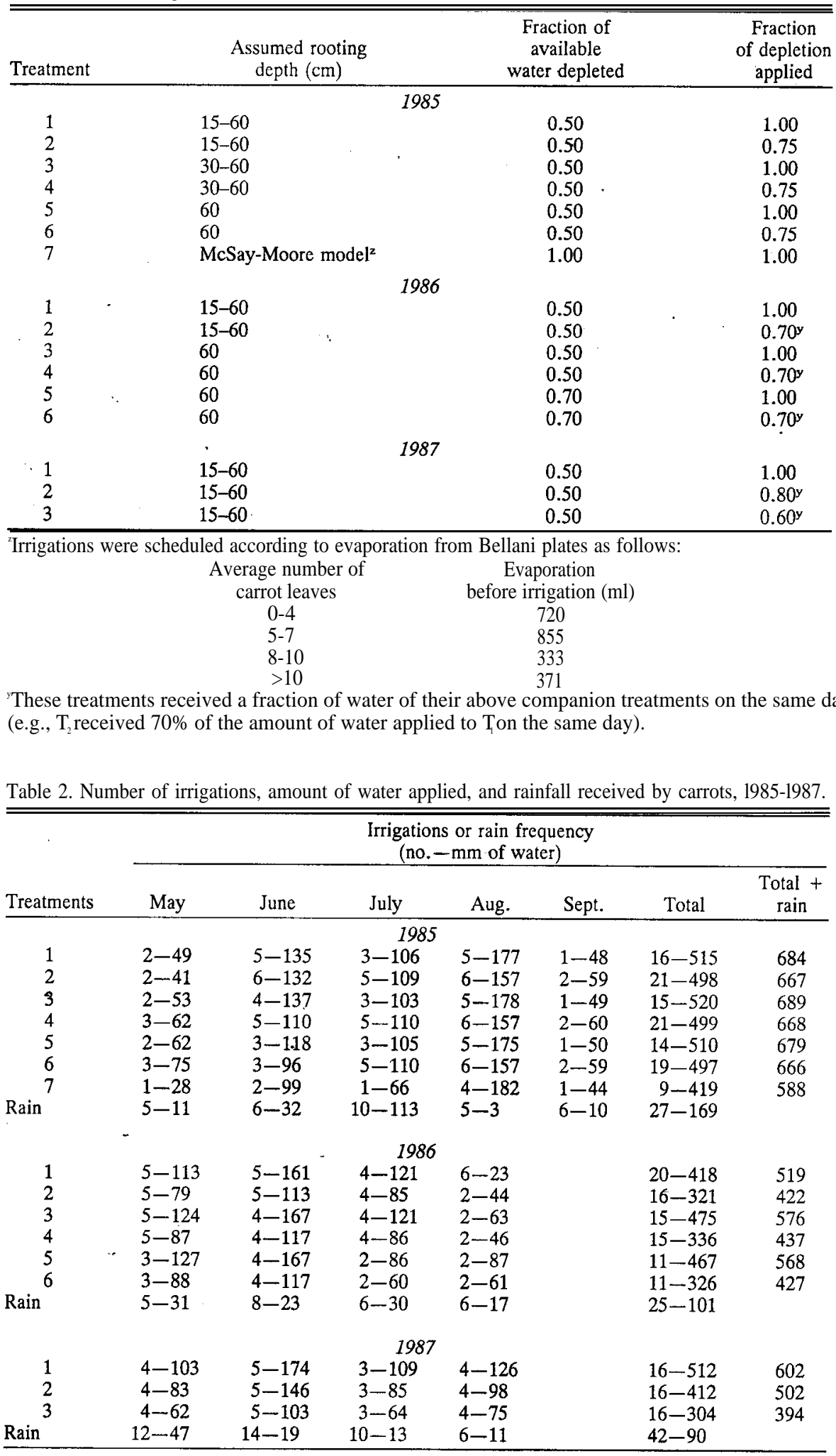

When soil water is depleted to a predetermined percentage, the program signals for an irrigation and specifies the amount of water to meter onto each plot. The program predicts irrigation dates up to 10 days in advance, assuming average weather conditions. This scheduling approach is referred to as the "USDA model" in this paper.

The weather data included relative humid- ity, temperature, daily wind run, precipitation, and solar radiation. Water use may increase following a rain or irrigation because of increased evaporation from the soil surface. When the moisture received from irrigation or rain exceeded the capacity of the root zone, the excess was recorded as deep percolation.

The USDA model has no provision for

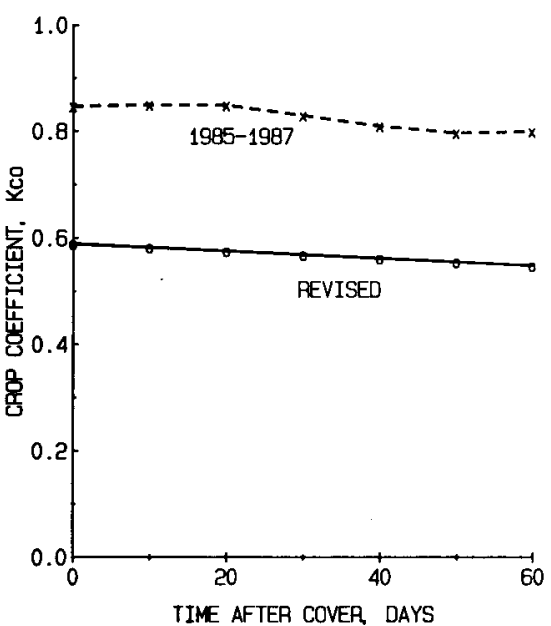

Fig. 2. Crop coefficient curves for irrigation scheduling of carrots after effective cover. The dashed line (1985-1987) represents the coefficients assumed for the 3-year field study. The revised curve (solid line) duplicates the irrigation treatment that gave highest yield and best water use efficiency in each of the three years.

estimating the amount of runoff that might occur during a downpour, which could conceivably result in runoff while leaving the root zone below field capacity. Should this happen, it would be desirable to estimate the amount of runoff and deduct it from the precipitation value entered into the program. Should runoff occur after the root zone has been recharged, no deduction is necessary.

The USDA model can be forced to call for more-frequent irrigations by assuming a shallower rooting zone or by specifying irrigation at a lower level of soil water depletion. The program will also call for more water if the crop coefficient is increased.

All experiments were conducted on the Colorado State Univ. Horticulture Research Center, northeast of Fort Collins, on a Nunn clay loam (Aridic Argiustoll) having a waterholding capacity of $99 \mathrm{~mm} \cdot \mathrm{m}^{-1}$. This soil was plowed in the fall and fertilized each spring according to soil test recommendations. After incorporating fertilizer, beds were prepared on $60-\mathrm{cm}$ centers and planted to 'Spartan Sweet' carrots on the following dates: 16 Apr. 1985, 1 May 1986, and 10 May 1987. In 1985 and 1986, the herbicide N'(3,4 -dichlorophenyl) -N-methoxy-N-methylurea (Lorox; linuron) at $1.4 \mathrm{~kg} \cdot \mathrm{ha}^{-1}$ (actual chemical) was applied over the seeded rows after planting. It was omitted in 1987.

A portable sprinkler system was used after planting to help establish a stand and to fully charge the root zone. The sprinkling dates were 10 May 1985, 6 May 1986, and 13 May 1987. The irrigation scheduling program was initiated after these dates. The water applied at this time and the rain that fell before these dates were not included in this study.

Each plot was $6.1 \mathrm{~m}$ long and $1.8 \mathrm{~m}$ wide, providing two harvest rows and one buffer row per plot. The plots were overseeded so that it was necessary to thin the carrots to a 25-mm spacing. Each treatment was rep- 
Table 3. Marketable carrot yields and water use efficiency (WUE) as influenced by irrigation treatment. ${ }^{2}$

\begin{tabular}{|c|c|c|c|c|}
\hline \multirow[b]{2}{*}{ Treatment } & $\begin{array}{c}\text { Small } \\
(12-44 \mathrm{~mm})\end{array}$ & $\begin{array}{c}\text { Large } \\
(>44 \mathrm{~mm})\end{array}$ & Total & \multirow{2}{*}{$\begin{array}{c}\text { WUE } \\
\left(\mathrm{kg} \cdot \mathrm{ha}^{-1} \cdot \mathrm{mm}^{-1}\right)\end{array}$} \\
\hline & \multicolumn{3}{|c|}{$\left(\mathrm{t} \cdot \mathrm{ha} \mathrm{a}^{-1}\right)$} & \\
\hline \multicolumn{5}{|c|}{1985} \\
\hline 1 & 9.5 & 5.7 & 15.2 & 22 \\
\hline 2 & 9.5 & 7.4 & 16.9 & 25 \\
\hline 3 & 8.8 & 6.3 & 15.1 & 22 \\
\hline 4 & 10.5 & 9.1 & 19.6 & 29 \\
\hline 5 & 11.1 & 7.1 & 18.2 & 27 \\
\hline 6 & 11.2 & 5.7 & 16.9 & 25 \\
\hline 7 & 8.8 & 4.5 & 13.3 & 23 \\
\hline • & NS & NS & NS & NS \\
\hline \multicolumn{5}{|c|}{1986} \\
\hline 1 & 17.3 & $12.9 \mathrm{a}$ & $30.2 \mathrm{a}$ & $58 \mathrm{ab}$ \\
\hline 2 & 16.8 & $13.1 \mathrm{a}$ & $29.9 \mathrm{a}$ & $71 \mathrm{a}$ \\
\hline 3 & 15.3 & $14.9 \mathrm{a}$ & $30.2 \mathrm{a}$ & $52 \mathrm{ab}$ \\
\hline 4 & 13.7 & $6.2 c$ & $19.9 \mathrm{~b}$ & $45 \mathrm{~b}$. \\
\hline 5 & V 17.4 & $11.7 \mathrm{ab}$ & $29.1 \mathrm{ab}$ & $51 \mathrm{ab}$ \\
\hline 6 & 15.5 & $8.0 \mathrm{bc}$ & $23.5 \mathrm{ab}$ & $55 \mathrm{ab}$ \\
\hline \multicolumn{5}{|c|}{ NS } \\
\hline \multicolumn{5}{|c|}{1987} \\
\hline 1 & 20.0 & $13.7 \mathrm{a}$ & $33.7 \mathrm{ab}$ & $56 \mathrm{~b}$ \\
\hline 2 & 25.4 & $13.5 \mathrm{ab}$ & $38.9 \mathrm{a}$ & 78 a \\
\hline \multirow[t]{2}{*}{3} & 22.3 & $7.1 \mathrm{~b}$ & $29.4 \mathrm{~b}$ & $75 \mathrm{a}$ \\
\hline & NS & . & & \\
\hline
\end{tabular}

'Values followed by different letters in a column are significantly different at $P=0.05$ using Duncan's multiple range test. NS at the end of a column means the values are not significantly different.

Table 4. Revised crop coefficient equations' and dates for USDA irrigation scheduling procedures for carrots, 1985-1987.

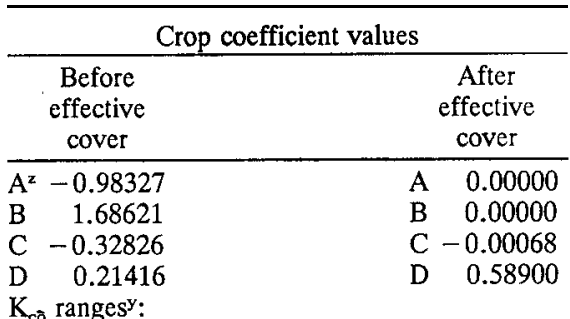

0.30 minimum, 0.60 maximum (Fig. 1)

${ }^{2}$ Crop coefficients are computed by $\mathrm{K}_{\mathrm{co}}=\mathrm{Ar}^{3}+$ $\mathrm{Br}^{2}+\mathrm{Cr}+\mathrm{D}$, where $\mathrm{K}$ is the crop coefficient used in the USDA irrigation scheduling program. Before effective cover, $r$ is the fraction of time from planting to effective cover. After effective cover, $r$ is measured in days (Fig. 1)-.

${ }^{y} \mathrm{~K}_{\mathrm{co}}$ values listed above are valid for carrot planting dates from 15 Apr. to 15 May. Effective cover was assumed to have occurred on 5 July. Rootzone depth is assumed to increase linearly from $30 \mathrm{~cm}$ at planting to $60 \mathrm{~cm}$ at effective cover and then remain constant. The program signals for an irrigation when $40 \%$ of available water in the root zone has been depleted.

Table 5. Comparison of actual and revised irrigation number and amounts on carrots for the best annual treatments, 1985-1987.

\begin{tabular}{lccc}
\hline Criterion & 1985 & 1986 & 1987 \\
\hline \multicolumn{4}{c}{ Actual (designated best treatment) } \\
Treatment & $\mathrm{T}_{4}$ & $\mathrm{~T}_{2}$ & $\mathrm{~T}_{2}$ \\
No. of irrigations & 21 & 16 & 16 \\
Water applied (mm) & 499 & 321 & 412
\end{tabular}

\begin{tabular}{lcrr} 
& Revised (simulated) & & \\
No. of irrigations & 20 & 14 & 16 \\
Water applied (mm) & 487 & 345 & 407 \\
\hline
\end{tabular}

${ }^{2}$ The values given resulted from rerunning weather data from these three years using revised coefficients and rooting depth assumptions. resented by four plots that were arranged in a randomized complete-block design. Plots were surface-irrigated by metering water into three furrows associated with each plot.

Domestic water (80 ppm salts) was applied through a flow-meter and an apparatus to divide the flow evenly into the three furrows. The furrows were blocked at both ends, assuring that all water applied was confined to the plot.

The treatments used for each of the three growing seasons were scheduled by the USDA model, except $\mathrm{T}_{7}$ of 1985 , which was scheduled by the McSay-Moore model (Table 1).

The McSay-Moore model uses Bellani plates (Carder, 1968) to determine when to irrigate (McSay and Moore, 1980). For $\mathrm{T}_{7}$, carrot growth was divided into four growth stages, as defined by the average number of leaves present. At each growth stage, a predetermined amount of water had to be evaporated from Bellani plates before an irrigation could take place. Two Bellani plates were used to assure a valid measurement if one plate malfunctioned. If there were no malfunctions, values from the two plates were averaged. Since the McSay-Moore model was developed for furrow irrigation systems, where water entering a field is often not measured, water requirements cannot be determined. Therefore, when an irrigation was called for, the amount applied was $100 \%$ of the depletion, as estimated by the USDA model. In 1985, the McSay-Moore model did not outperform the USDA model, which does have a feature that includes how much water to apply. Therefore, the McSay-Moore model was not used again.

Carrots were hand-harvested in October when cool weather had slowed growth. The center two rows in each plot were harvested, topped, and placed in labeled bags. Each bag of carrots was separated into small- (12 to $44 \mathrm{~mm}$ ) and large- (> $44 \mathrm{~mm}$ ) diameter, marketable roots. These roots were then counted and weighed.

The amount of water applied after the initial sprinkling dates and the number of irrigations received by each treatment are recorded in Table 2. An effective treatment is one that rises the minimum number of irrigations and minimum amount of water and still produces yields that are not significantly less than maximum.

There were no significant differences in yields or WUES in 1985 (Table 3). However, in 1986, there were differences in the large and total weight categories in WUES (Table 3). $T$, was most effective because it resulted in high WUE and was not statistically surpassed in yield by any other treatment. As shown in Table 1 , the $1986 \mathrm{~T}_{2}$ received $70 \%$ of the water applied to $\mathrm{T}_{1}$.

Because $T_{2}$ was the most effective treatment in 1986, three variations of this treatment were used for treatments in 1987. Again, the preferred treatment was $\mathrm{T}_{2}$, which, in 1987 , received $80 \%$ of the water applied to $\mathrm{T}_{\text {. }}$. Since the $70 \%$ level used in 1986 was not repeated, it is reasonable to conclude that $70 \%$ to $80 \%$ of full depletion, calculated with the originally assumed coefficients, is optimum for carrot production.

During 1985, the treatments scheduled by the USDA model that received 0.75 times estimated depletion at each irrigation were irrigated more frequently than the 1.00 times depletion treatments to maintain their soil moisture at the prescribed level. However, by irrigating frequently, the soil surface was wet longer, and the program increased its estimate of daily $E_{t}$ because of this wet soil surface. As a result, the frequently irrigated treatments used more water than we expected and significant yield differences did not materialize.

After 1985, this problem was avoided by irrigating all treatments on the same day so they would have equal amounts of surface evaporation. As a result, seasonal irrigation amounts differed enough to produce significant yield and WUE differences.

A common rule of thumb for irrigation scheduling is to irrigate when half the available water in the root zone has been depleted (Doorenbos and Pruitt, 1977). The 1986 results indicated that yields and WUES tended to be higher when carrots were irrigated at $50 \%$ depletion, as compared to $70 \%$. Therefore, in 1987, only $50 \%$ depletion was used. In 1987, highest yields and WUE resulted with $\mathrm{T}_{2}$. Since this treatment received only $80 \%$ of the estimated soil water depletion, it became apparent that the USDA program using the original coefficients was overestimating water use by carrots.

The 1987 field studies confirmed indications from 1985 and 1986 that the crop coefficients assumed at the beginning of this study (indicated by the 1985-1987 lines on Figs. 1 and 2) caused overly high estimates of $E$,. The 1987 field data showed that $\mathrm{T}_{2}$ gave the highest yields and highest WUE (Table 3). Therefore, after field studies were com- 
pleted, the crop coefficients used in the USDA irrigation scheduling program were revised. This was done by trial and error, until resimulations with 1987 weather data showed that the program would predict an irrigation regime similar to that applied to T, in 1987 . An equation for computing these revised coefficients is given in Table 4 and the revised coefficients are shown in Figs. 1 and 2 . Note that the revised coefficients would indicate early season $\mathrm{K}_{\mathrm{co}}$ values $<0.30$. However, a statement in the scheduling program specifies 0.30 as the minimum value of $\mathrm{K}_{\mathrm{co}}$. With the revised coefficients, it is also necessary to assume that the root-zone depth increases linearly from $30 \mathrm{~cm}$ at planting to $60 \mathrm{~cm}$ at effective cover and it is necessary to specify irrigations when $40 \%$ of the available soil water in the root zone is depleted.

Use of the revised coefficients in 1986 would have closely duplicated $\mathrm{T}_{2}$, the treatment that produced a high yield and the best WUE. In 1985, the revised coefficients would have given an irrigation regime similar to $\mathrm{T}_{4}$, which produced the highest, although not statistically significant, yield and WUE. Table 5 lists the number of irrigations and depth of water applied to the best treatment in each of the 3 years, and, for comparison, the same data if the revised crop coefficients and rooting assumptions had been used. We can conclude that the revised coefficients would have produced the best irrigation scheduling results for all 3 years of our study.

We recommend an irrigation scheduling program based on the revised coefficients (Table 4) for carrots in northern Colorado and similar climates to obtain the best combination of high yields and water use efficiency with a minimal number of irrigations. The irrigation scheduling program is available from E. G. K., J. E. E., and A.E.M. for use on IBM-compatible microcomputers

\section{Literature Cited}

Carder, A.C. 1968. The black Bellani-type atmometer as an instrument to estimate evapotranspiration of crop plants. Intl. J. Biometerol. 12(1):11-14.

Donahue, R. L., R.W. Mille, and J.C. Shickluna. 1977. Soils: An introduction to soils and plant growth. 4th ed. Prentice-Hall, Englewood Cliffs, N.J.

Doorenbos, J. and W.O. Pruitt. 1977. Guidelines for predicting crop water requirements. Food and Agr. Organization of the United Nations $\mathrm{hr}$. and Drainage Paper 24.

Hanan, J.T. 1987. So speaks the rose. Colorado Greenhouse Growers Assn. Res. Bul. 442:1-4.

Jackson, R.A. 1982. canopy temperature and crop water stress. Adv. Irr. 1:43-85.

Jensen, M.E. 1969. Scheduling irrigations with computers. J. Soil \& Water Conservation 24(8):193-195.

Kincaid; D.C. and D.F. Heermann. 1974. Scheduling irrigations using a programmable calculator. USDA/ARS Bul. NC-12.

McSay, A.E. and F.D. Moore, 111.1980. A model for scheduling lettuce irrigation. Colorado State Univ. Expt. Sta. Tech. Bul. 141.

Tyree, M.T. and H.T. Hammel. 1972. The measurement of turgor pressure and water relations of plants by the pressure bomb technique. J. Expt. Bet. 23(74):267-282.

\title{
Size and Flowering of Seed-propagated Geraniums in Response to Fungicide Drenching Schedules
}

\author{
M.K. Hausbeck ${ }^{1}$, C.T. Stephens ${ }^{2}$, and R.D. Heins ${ }^{3}$ \\ Michigan State University, East Lansing, MI 48824-1312
}

Additional index words. fenaminosulf, metalaxyl, Pelargonium $\times$ hortorum, Pythium

ultimum

Abstract. Two fungicides registered for the control of Pythium spp. were evaluated for their effects on size and time to flowering of seed-propagated geraniums (Pelargonium $\times$ hortorum L.H. Bailey). Fungicide drenches of fenaminosulf and metalaxyl were applied to geraniums grown in soilless root medium: 1) at seeding (S); 2) at seeding and transplanting (ST); 3) at seeding, transplanting, and 1 week after transplanting $(\mathrm{ST}+1)$; 4) at transplanting $(\mathrm{T})$; and 5$) 1$ week after transplanting $(\mathrm{T}+1)$. Metalaxyl drenching schedules did not significantly influence plant size or time to flowering. Fenaminosulf drenching schedules 3 and 4 significantly reduced plant size, and drenching schedule 3 significantly increased days to flowering in comparison to control plants. Although fenaminosulf is used infrequently because of limited availability, the detrimental effects of this fungicide on plant size and time to flowering warrant similar investigations with additional fungicides and crops. Chemical names used: sodium[4(dimethylamino) phenyl]diazenesulfonate (fenaminosulf); N-(2,6-dimethylphenyl) - N(methoxyacetyl) -DL-alanine methyl ester (metalaxyl).

Pythium spp. are important and often devastating pathogens of seed-propagated geraniums. Root rot and lower stem rot of young and mature geraniums caused by Pythium $\mathrm{ul}$ timum Trow can be a common occurrence among certain cultivars, causing considerable plant loss (Hausbeck et al., 1987; Powell, 1982). Less severe root rot may result in plant stunting and delay of flowering that may go unnoticed if silver thiosulfate (STS), a petal-shattering preventative, is not applied (Hausbeck et al., 1989a). Silver thiosulfate application to seed-propagated geraniums infected with even low levels of $P$. ultimum increases the incidence of plant death caused by pythium lower stem rot (Hausbeck et al., 1989b).

Current control practices for pythium root rot and lower stem rot of seed-propagated geraniums include sanitation and application of fungicides. Pythium spp. have been reduced or eliminated before planting by heating or fumigating of soil. Reintroduction of the pathogen into greenhouses may occur through water supply sources or irrigation ponds (Bewley and Buddin, 1921; Gill, 1970). Also, Pythium-infested soil particles from greenhouse walkways, floors, and beds

Received for publication 7 Apr. 1989. We acknowledge the Michigan Agricultural Experiment Station for their support of this project. The cost of publishing this paper was defrayed in part by the payment of page charges. Under postal regulations, this paper therefore must be hereby marked advertisement solely to indicate this fact.

'Former Graduate Research Assistant, Dept. of Horticulture. Present address: Dept. of Plant Pathology, Pennsylvania State Univ., University Park, PA 16802.

${ }^{2}$ Associate Professor, Dept. of Botany and Plant Pathology.

${ }^{3}$ Professor, Dept. of Horticulture. serve as inoculum that may be unknowingly transported throughout production areas by greenhouse personnel (Stephens et al., 1983; Stephens and Powell, 1982).

Several fungicides are recommended for control of diseases caused by Pythium spp. on seed-propagated geraniums (Powell, 1982; Stephens, 1984). Preventive fungicide treatment is warranted for production systems using STS but invariably involves fungicide applications to plants not infected with the targeted pathogen. The effects of such drenches on plant growth and time to flowering are seldom considered in disease management strategies, primarily due to lack of information. The objective of this study was to determine the effects of two fungicides registered to control Pythium spp. on the size and time to flowering of seed-propagated geraniums.

The fungicides fenaminosulf, $0.43 \mathrm{~g}$ a.i./ liter (Lesan 35\% WP, Mobay Chemical Corp., Kansas City, Me.), and metalaxyl, $0.101 \mathrm{~g}$ a.i./liter (Subdue 2E, 25\% emulsifiable concentrate, Ciba-Geigy, Greensboro, N. C.) were used in this study. Fungicide drenches were applied to plants grown in soilless root medium according to the following drenching schedules: 1) at seeding (S); 2) at seeding and transplanting (ST); 3) at seeding, transplanting, and 1 week after transplanting (ST $+1)$; 4) at transplanting (T); and 5) 1 week after transplanting $(\mathrm{T}+1)$. These drenching schedules encompass preventive control strategies that might be used by greenhouse operators and include those effective in controlling root rot and lower stem rot caused by $P$. ultimum (Hausbeck et al., 1988).

Geranium seeds (cultivar Ringo Scarlet) obtained from Sluis and Groot B. V., Enkhuizen, The Netherlands, were individually sown in round $2.0-\mathrm{cm}$-diameter cells $\left(6.3 \mathrm{~cm}^{3}\right)$ 